\title{
THE OPTIMIZATION OF ULTRASOUND-ASSISTED EXTRACTION OF TOTAL FLAVONOIDS FROM POT MARIGOLD (Calendulae officinalis L.) FLOWERS
}

Stanko A. Zerajić, Ivana M. Savić Gajić*, Ivan M. Savić, Goran S. Nikolić

Faculty of Technology, University of Niš, Leskovac, Serbia

Pot marigold (Calendula officinalis L.) contains various bioactive compounds such as flavonoids, tannins, saponosides, carotenoids, triterpene alcohols, polysaccharides, amino acids, and essential oil. The extract of pot marigold flower has a benefit to the skin due to the presence of flavonoids that possess the anti-inflammatory, astringent, antifungal, and antiseptic effects. The aim of this study was to apply the ultrasound-assisted extraction as an advanced extraction technique and to investigate the impact of extraction time (5-35 min), ethanol concentration (20-80\%, v/v), and extraction temperature $\left(30-70{ }^{\circ} \mathrm{C}\right)$ on the total flavonoid content of pot marigold flower at the liquid-to-solid ratio of $20 \mathrm{~cm}^{3} \mathrm{~g}^{-1}$. The total flavonoids content of the extracts was determined spectrophotometrically with aluminium (III) chloride. The modeling of ultrasound-assisted extraction was carried out using a Box-Behnken design. Thus found optimal extraction conditions were the extraction time of $29 \mathrm{~min}$, $39.6 \%(\mathrm{v} / \mathrm{v})$ ethanol, and extraction temperature of $64.2^{\circ} \mathrm{C}$. The experimental value

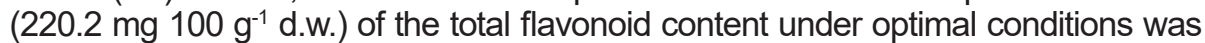
in a good agreement with the predicted value (221.5 mg $100 \mathrm{~g} \mathrm{~g}^{-1} \mathrm{~d}$.w.). According to the results of statistical analysis, the proposed second-order polynomial equation can be used to describe the extraction of flavonoids and to predict the total flavonoid content. The extraction procedure can be accepted from the point of the pharmaceutical application due to the use of ethanol as a representative of green solvents. The extraction time was shorter compared with other conventional extraction techniques.
(ORIGINAL SCIENTIFIC PAPER) UDC 66.061:582.998:547.972.3

Keywords: ultrasound-assisted extraction, flavonoids, Calendulae officinalis, Box-Behnken.

\section{Introduction}

Pot marigold (Calendula officinalis L.) originates from the Mediterranean [1], and grows in the gardens and parks of Central and Southern Europe, Western Asia and USA [2]. It reaches a height between 30 and $60 \mathrm{~cm}[2,3]$. Its flower has yellow or orange colour and a unique fragrance [3]. Therapeutic properties of the flower are attributed to various types of bioactive compounds, such as: flavonoids, tannins, saponosides, carotenoids, triterpene alcohols, polysaccharides, amino acids, and essential oils [2, 4-6]. The extract of pot marigold flower has the antioxidant [7-12], antimicrobial [13-15], anti-inflammatory [16,17], anticancer [18,19], spasmolytic [20], hepatoprotective, and rheumatic protective activities [21]. Due to the complex chemical content and broad spectrum of pharmacological activity, this plant material has an application in pharmaceutical and cosmetic industries. The pot morigold is described in German and the Russian Pharmacopoeia, as well as in the supplement of European Pharmacopoeia 6.0 [22], but is not described by Yugoslavian Pharmacopoeia V [23]. In folk medicine, it is used as a mild antiseptic for outdoor and indoor use in the form of tea, tincture, and ointment. Tea is effective in the treatment of inflammation of the gastro-system, bile, hemorrhoids, veins, and capillaries. It causes sweating, cleans the liver, restores the viscosity of the blood, calms the open wounds, stains, mites, and aging spots [24]. In the official medicine, it is used for the symptomatic treatment of mild skin inflammations (burns from the sun), minor wounds and inflammation of the oral cavity [25].

The hydrodistillation of the essential oil from fresh flowers of pot marigold have been described in British Pharmacopoeia [26], while the preparation of its tincture with $40 \%$ $(\mathrm{v} / \mathrm{v})$ and $60 \%(\mathrm{v} / \mathrm{v})$ ethanol was proposed in European Pharmacopoeia [27]. Matysik et al. [28] quantified flavonoids and pentacyclic triterpene in methanol, ethyl acetate and heptane extracts using a chromatographic method. The extracts were prepared by reflux extraction at the temperature of $60^{\circ} \mathrm{C}$ for $5 \mathrm{~h}$. Bakó et al. [6] prepared the methanolic extract by maceration in order to identify carotenoids in the plant material. The plant material was treated by the solvent at room temperature for $20 \mathrm{~h}$. The ethanolic extract obtained using maceration was used to analyze the hepatoand reno-protective functions of the pot marigold extract [21].

\footnotetext{
*Author address: Ivana M. Savić Gajić, Faculty of Technology,

Bulevar oslobodjenja 124, 16000 Leskovac, Serbia

E-mail: vana.savic@yahoo.com

The manuscript received: April, 06, 2019.

Paper accepted: April, 20, 2019.
} 
The thin-layer chromatographic method was used to identify bioactive compounds and estimate the pharmacological activity of the n-hexane and methanolic extracts obtained using Soxhlet extraction at $70{ }^{\circ} \mathrm{C}$ for $8 \mathrm{~h}$ [29]. The ethanolic and methanolic extracts obtained at $35^{\circ} \mathrm{C}$ for $24 \mathrm{~h}$ were subjected to define their antimicrobial activity [14]. Recently, the main effort in many studies was focused in the direction of the development of the advanced extraction techniques that are more superior to other available conventional methods. A supercritical carbon dioxide extraction technique is one of them used for the preparation of the pot marigold extract $[11,30]$ and for obtaining the essential oil [31]. The ultrasound-assisted extraction as an advanced extraction technique provides the higher extraction yield of about $34 \%$ compared to the conventional extraction technique [32]. García-Risco et al. [11] confirmed that the extract obtained by using $50 \%(\mathrm{v} / \mathrm{v})$ ethanol and the ultrasound-assisted extraction has a higher phenolic content than the extract prepared by using pure ethanol.

The ultrasound-assisted extraction represents the technique of choice for the extraction of flavonoids from pot marigold. The simultaneous impact of different parameters on the yield of flavonoids has not been reported yet in the literature so that the aim of this paper was to investigate the impact of the extraction time, ethanol concentration, and extraction temperature on the total flavonoid content (TFC) of pot marigold. The TFC was determined using a spectrophotometric method with aluminium(III) chloride. BoxBehnken design was employed to model the extraction procedure and to define the interactions between investigated extraction parameters. The application of the design reduced the number of experimental runs needed for optimization compared to the one-variable-at-a-time method.

\section{Experimental}

\section{Materials}

Chemicals and reagents

Rutin trihydrate (purity of 97\%) (Alfa Aesar - Johnson Matthey Company, Heysham, Great Britain), methanol, 96\% ethanol (Zorka Pharma, Šabac, Republic of Serbia), aluminium(III) chloride, potassium acetate (Sigma Chemical, Saint Louis, Missouri, USA) were used.

\section{Plant material}

Pot marigold (Calendulae officinalis L.) flowers were purchased from "Josif Pančić" (Belgrade, Republic of Serbia). The moisture content of $14.4 \%$ (w/w) was determined by drying of the plant material in a laboratory oven at $105^{\circ} \mathrm{C}$ until the constant mass.

\section{Methods}

Extraction procedure of pot marigold flowers

The extractions assisted by ultrasound were performed in an ultrasonic bath (Sonic, Niš, Republic of Serbia). The used frequency was $40 \mathrm{kHz}$, while the power was $150 \mathrm{~W}$. The liquid-to-solid ratio was $20 \mathrm{~cm}^{3} \mathrm{~g}^{-1}$. After extraction, the plant material was separated by filtration under vacuum.
The extract was evaporated under vacuum at $50^{\circ} \mathrm{C}$ and stored in a desiccator before further analysis.

\section{Box-Behnken design}

The three extraction parameters (extraction time, ethanol concentration, and extraction temperature) were varied at three levels $(-1,0,+1)$ according to the Box-Behnken design, representing an alternative to a central composite design. The design which represents a combination of a fractional factorial design and an incomplete block design [33] is suitable for optimization of the extraction process [34]. The TFC was defined as a design response.

According to Equation 1, the actual factors $\left(x_{i}\right)$ were converted to coded for better uniformity [33].

$x_{\mathrm{i}}=\frac{x_{\mathrm{i}}-x_{\mathrm{o}}}{\Delta x_{\mathrm{i}}}$

where $X_{i}$ - coded value of factor, $x_{i}$ - actual value of factor, $x_{o}$ - actual value in the center point, $\Delta x_{i}$ - the step change of value. In Table 1, the levels of the analyzed factors are depicted.

Table 1. Coded and actual values of factor levels

\begin{tabular}{|c|c|c|c|c|c|c|}
\hline \multirow{2}{*}{ Factors } & \multirow{2}{*}{\multicolumn{2}{|c|}{ actual }} & \multirow{2}{*}{ coded } & \multicolumn{3}{|c|}{ Factor levels } \\
\hline & & & & 1 & 0 & +1 \\
\hline Extraction time [min] & $x_{1}$ & & $X_{1}^{*}$ & 5 & 20 & 35 \\
\hline Ethanol concentration $[\%, v / v]$ & $x_{2}$ & & $X_{2}^{* *}$ & 20 & 50 & 80 \\
\hline Extraction temperature $\left[{ }^{\circ} \mathrm{C}\right]$ & $x_{3}$ & & $X_{3}^{* *}$ & 30 & 50 & 70 \\
\hline${ }^{*} X_{1} \quad x_{1}-2 \quad / 15 ;{ }^{* *} X_{2} \quad x_{2}-5$ & $130 ;{ }^{* * *} X_{3}$ & $x_{3}-5$ & $/ 20$ & & & \\
\hline
\end{tabular}

The 17 extractions were performed in order to apply this design for modeling of the extraction process. The extraction of flavonoids was described using a secondorder polynomial equation (Equation 2) [34]:

$$
\begin{aligned}
& Y=a_{\mathrm{o}}+a_{1} x_{1}+a_{2} x_{2}+a_{3} X_{3}+a_{11} X_{1}^{2}+a_{22} x_{2}^{2}+a_{33} x_{3}^{2}+ \\
& +a_{12} x_{1} x_{2}+a_{13} x_{1} x_{3}+a_{23} x_{2} x_{3}+\varepsilon
\end{aligned}
$$

where $Y$ - system response (TFC); $x_{1}, x_{2}, x_{3}$ - factors; $a_{0}$ - intercept; $a_{1}, a_{2}, a_{3}, a_{11}, a_{22}, a_{33}, a_{12}, a_{13}, a_{23}$-regression coefficients, and $\varepsilon$ - residual. The parameter $\varepsilon$ represents the model error (lack-of-fit) and the experimental error (pure error).

The coefficients of the polynomial equation were determined using the method of the least squares. Design Expert 11.0.3.0 (Stat-Ease, Minneapolis, Minnesota, USA) was used for a statistical analysis of the proposed regression model. The effect of analyzed factors was estimated based on the analysis of variance (ANOVA).

The terms in the polynomial equation were analyzed and statistically verified using F-test with a 95\% confidence interval $(p<0.05)$. Based on the coefficient of determination, the adequacy of model was confirmed.

Determination of total flavonoid content

The TFC of pot marigold was determined according to a standard procedure with aluminium(III) chloride [35]. 
The content was expressed as milligram rutin equivalent per $100 \mathrm{~g}$ of the dry weight $\left(\mathrm{mg}_{\mathrm{RE}} 100 \mathrm{~g}^{-1} \mathrm{~d}\right.$.w. $)$. The stock solution of rutin $\left(1.0 \mathrm{mg} \mathrm{cm}^{-3}\right)$ in methanol was used to prepare a series of solutions in the concentration range of $1-100 \mu \mathrm{g} \mathrm{cm}^{-3}$. The sample consisted of $2.0 \mathrm{~cm}^{3}$ of a methanolic solution of rutin (or the extract), $0.1 \mathrm{~cm}^{3}$ of aluminium(III)-chloride $(10 \%, \mathrm{w} / \mathrm{w}), 0.1 \mathrm{~cm}^{3}$ of potassium acetate $\left(1 \mathrm{~mol} \mathrm{dm}^{-3}\right)$, and $2.8 \mathrm{~cm}^{3}$ of distilled water. Instead of aluminium(III) chloride, a blank solution contained the equivalent amount of distilled water. Varian Cary-100 Conc (Mulgrave, Victoria, Australia) spectrophotometer was employed to measure the absorbance of the samples at $415 \mathrm{~nm}$ in a quartz cuvette of $1 \times 1 \mathrm{~cm}$ at room temperature $\left(22^{\circ} \mathrm{C}\right)$.

\section{Results and discussion}

\section{Modeling the extraction procedure}

The content of the extract depends on the used solvent and the extraction method [36]. Green solvents have the advantage for the extraction of bioactive compounds from plant materials compared with other solvents since the obtained extract can be used in food, pharmaceutical, and cosmetic industries [37]. Among them, ethanol is commonly used as a solvent due to its properties, such as non-toxicity and eco-frendly to obtain the extract of the desired content. Since the flavonoid content depends on the solvent polarity [38], the impact of different ethanol concentrations was analyzed in this study. The calibration curve of rutin (Equation 3 ) was used to determine the TFC in the extracts:

$A_{415}=14.2 C_{R}+0.05$

$$
\left(R^{2}=0.999\right)
$$

where $A_{415}$ - absorbance at $415 \mathrm{~nm}$ expressed in $A U, C_{R}$ - concentration of rutin expressed in $\mathrm{mg} \mathrm{cm}^{-3}$. Linearity of the calibration curve was noticed in the concentration range of $5-100 \mu \mathrm{g} \mathrm{cm}^{-3}$.

Before the optimization using Box-Behnken design, the statistically significant factors (extraction time, ethanol concentration, and extraction temperature) were confirmed using a screening design. According to a matrix of Box-Behnken design presented in Table 2, the factors were varied as presented. In addition to the random order of extractions representing the combination of different factor levels, the experimental and predicted values of TFC are also given. The experimental TFC values were in the range between 114.7 and $221.0 \mathrm{mg}_{\mathrm{RE}} 100$ $\mathrm{g}^{-1} \mathrm{~d}$.w., so that flavonoids are approximately $0.2 \%$ of the dry plant material.

Table 2. Matrix of Box-Behnken design with experimental and the predicted total flavonoid content

\begin{tabular}{|c|c|c|c|c|c|c|c|}
\hline \multirow{2}{*}{ Std. } & \multirow{2}{*}{ Run } & \multirow{2}{*}{$\begin{array}{l}\text { Extraction time } \\
\text { [min] }\end{array}$} & \multirow{2}{*}{$\begin{array}{c}\text { Ethanol } \\
\text { concentration } \\
{[\%, v / v]}\end{array}$} & \multirow{2}{*}{$\begin{array}{c}\text { Extraction } \\
\text { temperature } \\
{\left[{ }^{\circ} \mathrm{C}\right]}\end{array}$} & \multicolumn{2}{|c|}{ TFC $\left[m_{R E} 100 \mathrm{~g}^{-1}\right.$ d.w.] } & \multirow{2}{*}{$\begin{array}{l}\text { Cook's } \\
\text { distance }\end{array}$} \\
\hline & & & & & Exp. & Pred. & \\
\hline 2 & 1 & 35 & 20 & 50 & 206.0 & 200.4 & 0.71 \\
\hline 16 & 2 & 20 & 50 & 50 & 210.0 & 202.0 & 0.04 \\
\hline 9 & 3 & 20 & 20 & 30 & 160.8 & 161.3 & 0.01 \\
\hline 10 & 4 & 20 & 80 & 30 & 121.9 & 115.8 & 0.85 \\
\hline 5 & 5 & 5 & 50 & 30 & 136.9 & 137.5 & 0.01 \\
\hline 11 & 6 & 20 & 20 & 70 & 171.7 & 177.9 & 0.85 \\
\hline 14 & 7 & 20 & 50 & 50 & 208.1 & 202.0 & 0.02 \\
\hline 3 & 8 & 5 & 80 & 50 & 118.0 & 123.6 & 0.71 \\
\hline 13 & 9 & 20 & 50 & 50 & 195.1 & 202.0 & 0.03 \\
\hline 12 & 10 & 20 & 80 & 70 & 168.1 & 167.6 & 0.01 \\
\hline 7 & 11 & 5 & 50 & 70 & 172.5 & 167.4 & 0.59 \\
\hline 1 & 12 & 5 & 20 & 50 & 114.7 & 113.7 & 0.02 \\
\hline 15 & 13 & 20 & 50 & 50 & 196.8 & 202.0 & 0.02 \\
\hline 17 & 14 & 20 & 50 & 50 & 199.9 & 202.0 & 0.00 \\
\hline 6 & 15 & 35 & 50 & 30 & 176.8 & 181.9 & 0.59 \\
\hline 4 & 16 & 35 & 80 & 50 & 133.5 & 134.5 & 0.02 \\
\hline 8 & 17 & 35 & 50 & 70 & 221.0 & 220.5 & 0.01 \\
\hline
\end{tabular}

The TFC was fitted using the second-order polynomial model containing linear and quadratic terms. The model and coefficients of the equation were obtained by statistical non-linear regression of experimental data. The polynomial model establishes the relationship between the factors and the response. The most acceptable model is defined by the highest coefficient of correlation (R) and the coefficient of determination $\left(R^{2}\right)$. In an ideal case, these values are 1 , indicating a good agreement between the experimental and predicted values [39]. The 
regression coefficients of the polynomial equation with the coded and actual factors, as well as the coefficients of determination are given in Table 3. The equation in terms of actual factors is used for the prediction of the response and is not used when determining the relative effect of each individual factor. For this reason, the importance of each term was estimated based on the regression coefficients in the equations with coded factors.
The positive regression coefficient indicates a positive impact on the TFC in the extracts and vice versa. The analysis of linear effects in the equation indicated that the ethanol concentration had a negative impact on the TFC [40]. The highest impact had the extraction time and then follows the extraction temperature and the ethanol concentration.

Table 3. The regression coefficients of the second-order polynomial equation with coded and actual values of factors

\begin{tabular}{lcc}
\hline \multicolumn{1}{c}{ Factor } & \multicolumn{2}{c}{ Coefficient } \\
& Coded factor & Actual factor \\
\hline Intercept & 201.98 & -32.30 \\
A-extraction time & 24.39 & 6.73 \\
B-ethanol concentration & -13.97 & 4.09 \\
C-extraction temperature & 17.1 & 1.55 \\
AB & -18.95 & -0.04 \\
AC & 2.16 & 0.01 \\
BC & 8.82 & 0.01 \\
$A^{2}$ & -18.89 & -0.08 \\
$B^{2}$ & -40.05 & -0.04 \\
$C^{2}$ & -6.28 & -0.02 \\
\hline
\end{tabular}

Table 3. The regression coefficients of the second-order polynomial equation with coded and actual values of factors

\begin{tabular}{|c|c|c|c|c|c|}
\hline & $\begin{array}{l}\text { Sum of } \\
\text { squares }\end{array}$ & $\begin{array}{c}\text { Degrees of } \\
\text { freedom }\end{array}$ & Mean squares & F-value & $p$-value \\
\hline Model & 19429.25 & 9 & 2158.81 & 40.20 & $<0.0001^{*}$ \\
\hline $\mathrm{X}_{1}$ & 4760.44 & 1 & 4760.44 & 88.64 & $<0.0001^{*}$ \\
\hline $\mathrm{X}_{2}$ & 1560.76 & 1 & 1560.76 & 29.06 & $0.001^{*}$ \\
\hline $\mathrm{X}_{3}$ & 2338.50 & 1 & 2338.50 & 43.55 & $0.0003^{*}$ \\
\hline $\mathrm{X}_{1} \mathrm{X}_{2}$ & 1436.89 & 1 & 1436.89 & 26.76 & $0.0013^{*}$ \\
\hline$X_{1} X_{3}$ & 18.64 & 1 & 18.64 & 0.35 & $0.5743^{* *}$ \\
\hline $\mathrm{X}_{2} \mathrm{X}_{3}$ & 310.98 & 1 & 310.98 & 5.79 & $0.0470^{*}$ \\
\hline $\mathrm{X}_{1}{ }^{2}$ & 1502.51 & 1 & 1502.51 & 27.98 & $0.0011^{*}$ \\
\hline $\mathrm{X}_{2}{ }^{2}$ & 6754.50 & 1 & 6754.50 & 125.78 & $<0.0001^{*}$ \\
\hline$X_{3}{ }^{2}$ & 166.18 & 1 & 166.18 & 3.09 & $0.1220^{* *}$ \\
\hline Residual & 375.92 & 7 & 53.70 & & \\
\hline Lack-of-fit & 196.20 & 3 & 65.40 & 1.46 & $0.3525^{\star *}$ \\
\hline Pure error & 179.72 & 4 & 44.93 & & \\
\hline Cor. total & 19805.17 & 16 & & & \\
\hline Std. dev. & 7.33 & & $\mathrm{R}^{2}$ & 0.981 & \\
\hline Mean & 171.29 & & $\mathrm{R}^{2}{ }_{\mathrm{adj}}$ & 0.957 & \\
\hline \multirow[t]{2}{*}{ C.V. \% } & 4.28 & & $\mathrm{R}^{2}$ pred & 0.827 & \\
\hline & & & Adequate precision & 19.00 & \\
\hline
\end{tabular}


The coefficient of determination of 0.981 indicated that a $1.9 \%$ variation in the TFC could not be explained by the regression model. The predicted coefficient of determination (0.827) was in good agreement with the adjusted coefficient of determination (0.957), given that the difference between these two values was less than 0.2 [41]. A detail statistical analysis was carried out in order to confirm the reliability of the chosen model. ANOVA of the proposed model is given in Table 4. The model F-value of 40.2 implied that the regression model was statistically significant. The lack-of-fit was not statistically significant comparing to pure error (179.72), because its F-value of 1.46 was lower than the critical value of 6.59 . The statistically insignificant lack-of-fit indicated that the proposed model was adequate for the prediction of response. The adequate precision of 19.00 implied a good signal-to-noise ratio. Since this value was higher than the limited value of 4 [42], the model can be used to navigate the design space.

The $p$-value for statistically significant terms was lower than 0.05 [42]. Not statistically significant terms in the polynomial equation were the interaction between the extraction time and the extraction temperature, as well as the quadratic effect of the textraction temperature. In order to improve the regression model, these terms can be excluded from the proposed polynomial equation.

Since the data follow the linearity in the normal probability plot of studentized residuals presented in Figure 1, it can be concluded that the residuals have normal distribution [34]. The analysis of Cook's distances (Table 2) indicated that there were no significant points (outliers) because all values of TFC were lower than the critical value of 1.0 .



Externally studentized residuals

Figure 1. Normal probability plot of studentized residuals.

The three-dimensional plots were a suitable graphical method to investigate the interactions between factors and their impact on the TFC. In Figure 2, the impact of the extraction time and the ethanol concentration at the extraction temperature of $50{ }^{\circ} \mathrm{C}$ is depicted. The surface shape indicated a strong interaction between analyzed factors. The increase of the extraction time leads to the increase of TFC which is more expressed for shorter than $15 \mathrm{~min}$. This was expected because of the rapid period of extraction which occurs in the first extraction time. Using this extraction technique, the increase of mass transfer velocity and destroyed plant cells are possible to achieve after the effect of cavitation energy [43]. The effect of the extraction time was more significant at lower ethanol concentrations $(<50 \%, v / v)$.

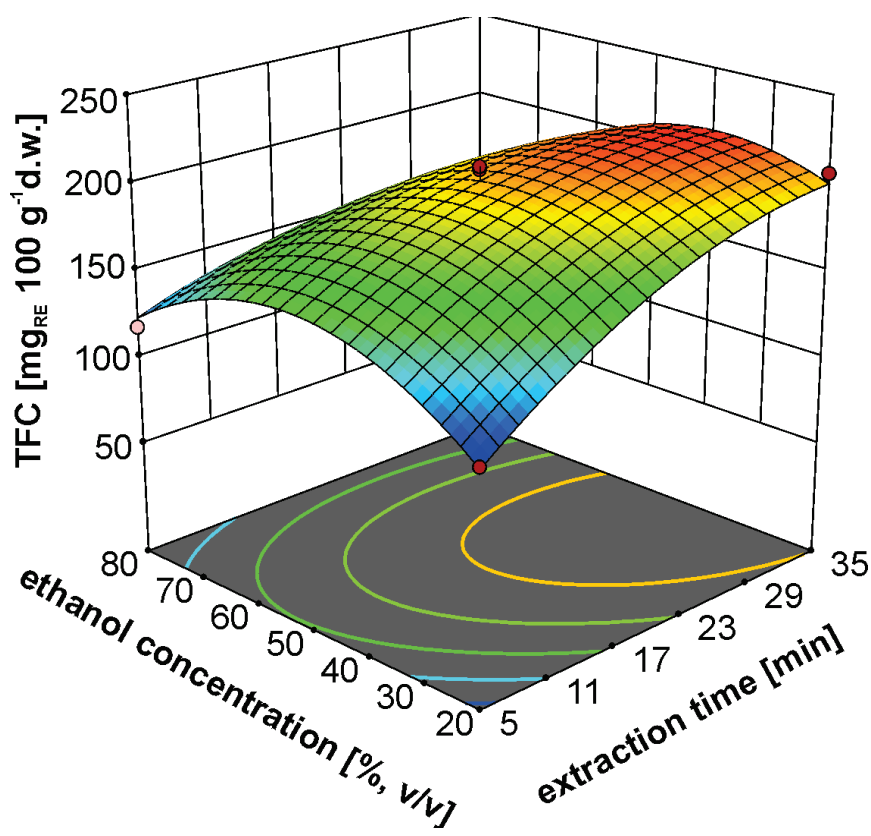

Figure 2. The impact of the extraction time and the ethanol concentration on the total flavonoid content at the extraction temperature of $50{ }^{\circ} \mathrm{C}$.

In Figure 3, the interaction between the ethanol concentration and the extraction temperature for the extraction time of $20 \mathrm{~min}$ is presented. The increase of the ethanol concentration especially above $50 \%(\mathrm{v} / \mathrm{v})$ leads to a decrease of TFC in the extracts. After the analysis of the diagram, it can be concluded that the extraction temperature has a positive impact on the TFC. The diffusion increases not only because of the increase of the extraction temperature but also due to improved hydrodynamic conditions [44]. Namely, the viscosity of the solvent decreases with increasing the temperature, which increases the penetration rate in the plant material, and consequently the concentration of flavonoids in the extract [45].

The impact of the extraction time and the extraction temperature on the TFC using $50 \%(\mathrm{v} / \mathrm{v})$ ethanol is depicted in Figure 4. It is clearly observed that the TFC was increased with increasing the extraction temperature for the same extraction time. This effect is more pronounced at longer extraction times (>20 min). The extraction time 
influences positively on the TFC at the constant extraction temperature; it can be clearly seen that this factor has a positive effect on the TFC.



Figure 3. The impact of the ethanol concentration and the extraction temperature on the total flavonoid content for the extraction time of $20 \mathrm{~min}$.

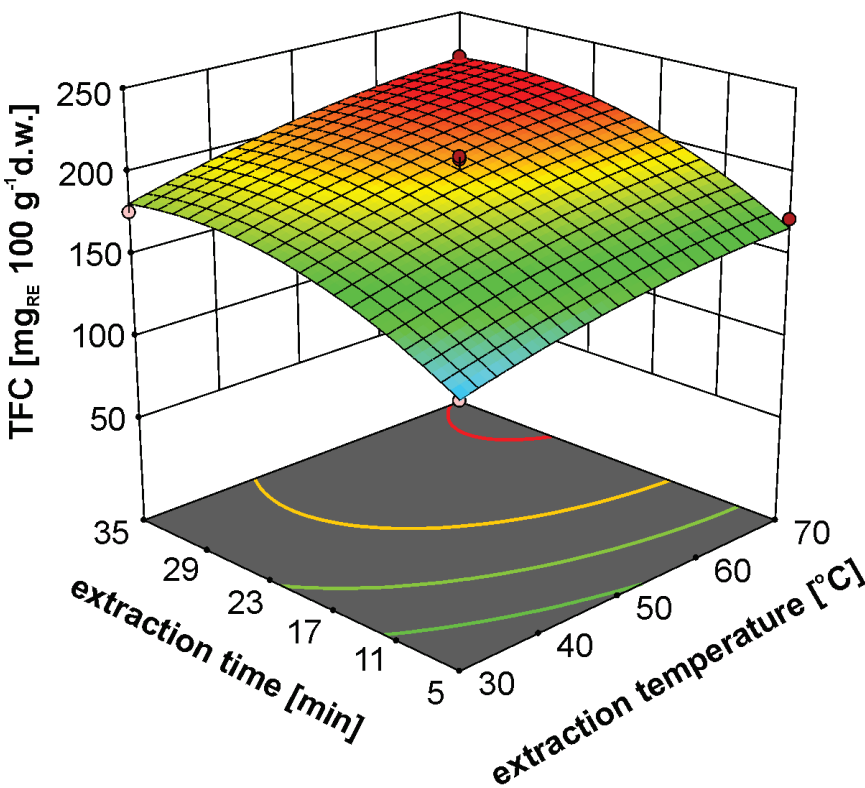

Figure 4. The impact of the extraction time and the extraction temperature on the total flavonoid conent using $50 \%$ (v/v) ethanol.

\section{Optimization of the extraction procedure}

Numerical optimization method was used to obtain the optimal extraction conditions. The TFC was maximized and the following conditions were obtained: the extraction time of $29 \mathrm{~min}$, the ethanol concentration of approximately $40 \%(\mathrm{v} / \mathrm{v})$, and the extraction temperature of approximately $64{ }^{\circ} \mathrm{C}$ (Figure 5) at the liquid-to-soild ratio of $20 \mathrm{~cm}^{3} \mathrm{~g}^{-1}$. Under these conditions, the regression

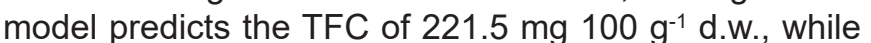

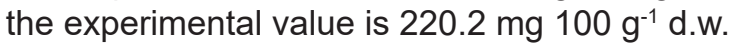

The extraction under optimal conditions was per- formed to estimate the prediction ability of the proposed model. A good agreement between these two values indicates the adequate prediction ability.
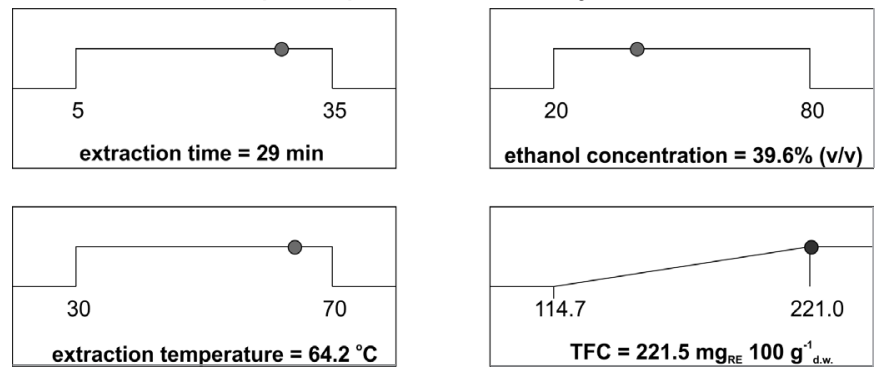

Figure 5. The optimal conditions of the flavonoid extraction from pot marigold flowers.

The TFC depends on the extraction techniques, solvents, and used procedures for its determination. The extract of pot marigold prepared by maceration using $70 \%(\mathrm{v} / \mathrm{v})$ ethanol has the TFC of $1.45 \%$ [1]. Jurca et al. [12] defined the TFC as milligram quercetin equivalent per $100 \mathrm{~g}$ of the dry weight $\left(\mathrm{mg}_{\mathrm{QE}} 100 \mathrm{~g}^{-1} \mathrm{~d}\right.$.w.). In the lyophilized and alcoholic extracts obtained by maceration with $95 \%(\mathrm{v} / \mathrm{v})$ ethanol at $20^{\circ} \mathrm{C}$ for $72 \mathrm{~h}$, the TFC was $266.62 \mathrm{mg}_{\mathrm{QE}} 100 \mathrm{~g}^{-1}$ d.w. and $42.12 \mathrm{mg}_{\mathrm{QE}} 100 \mathrm{~g}^{-1}$ d.w., respectively [12]. Bilia et al. [46,47] determined the TFC of $58.4 \mathrm{mg} 100 \mathrm{~cm}^{-3}$ and $57.1 \mathrm{mg} 100 \mathrm{~cm}^{-3}$ in the tinctures prepared using $40 \%(\mathrm{v} / \mathrm{v})$ i $60 \%(\mathrm{v} / \mathrm{v})$ ethanol, respectively. García-Risco et al. [11] reported that the extract obtained by ultrasound-assisted extraction with $50 \%$ $(\mathrm{v} / \mathrm{v})$ ethanol has the higest TFC of $50 \mathrm{mg}_{\mathrm{OE}} \mathrm{g}^{-1}$ of the extract compared with the extracts obtained by ultrasoundassisted extraction ( $25 \mathrm{mg}_{\mathrm{QE}} \mathrm{g}^{-1}$ of the extract) with absolute ethanol and by supercritical fluid extraction ( $>25$ $\mathrm{mg}_{\mathrm{QE}} \mathrm{g}^{-1}$ of the extract).

\section{Conclusion}

The extraction of flavonoids from pot marigold flowers assisted by ultrasound was described using the second-order polynomial equation. Box-Behnken design was successfully applied for the optimization of the extraction process. The impact of three factors: extraction time, ethanol concentration, and extraction temperature on the TFC was analyzed at the liquid-to-solid ratio of $20 \mathrm{~cm}^{3} \mathrm{~g}^{-1}$. The extraction time had the highest impact, while the extraction temperature and the ethanol concentration had a slightly lower impact. The linear effect of the ethanol concentration had a negative impact on the content of TFC in the extract. The optimal conditions: extraction time of $29 \mathrm{~min}, \sim 40 \%(\mathrm{v} / \mathrm{v})$ ethanol, and approximately extraction temperature of $64^{\circ} \mathrm{C}$ were obtained after the application of the numerical optimization method. The experimental (220.2 mg $100 \mathrm{~g} \mathrm{~g}^{-1}$ d.w.) and predicted (221.5 mg $100 \mathrm{~g} \mathrm{~g}^{-1}$ d.w.) values under optimal conditions, as well as the coefficients of determination were in good agreement. The adequate precision of 19 was higher than the required minimum of 4 . This value indicated the adequate signal-to-noise ratio of this model. Based 
on these facts, the proposed model can be used for the prediction of TFC in the design space. The proposed procedure for the extraction of flavonoids is acceptable for the application in the pharmaceutical industry due to the use of ethanol as a green solvent. The ultrasoundassisted extraction was an efficient advanced extraction technique because time for the extraction of flavonoids was reduced.

\section{Acknowledgment}

The authors acknowledge the financial support for this study from the Ministry of Education, Science and Technological Development of the Republic of Serbia by Grant No. TR-34012.

\section{References}

[1] K. Gurzulov, M. Marčetić, D. Božić, Investigation of quality and antimicrobal activity of cultivated marigold flowers Calendula officinalis L., Medical Youth, 67(2) (2016) 73-79.

[2] B. P. Muley, S. S. Khadabadi, N. B. Banarase, Phytochemical constituents and pharmacological activities of Calendula officinalis Linn (Asteraceae): a review, Tropical Journal of Pharmaceutical Research, 8(5) (2009) 455-465.

[3] J. Tucakov, Lečenje biljem: fitoterapija, Rad, Beograd 1984. (in Serbian)

[4] V. A. Kurkin, O. V. Sharova, Flavonoids from Calendula officinalis flowers, Chemistry of Natural Compounds, 43(2) (2007) 216-217.

[5] B. Król, Yield and the chemical composition of flower heads of pot marigold (Calendula officinalis L. cv. Orange King) depending on nitrogen fertilization, Acta Scientiarum Polonorum Hortorum Cultus, 10(2) (2011) 235-243.

[6] E. Bakó, J. Deli, G. Toth, HPLC study on the carotenoid composition of Calendula products, Journal of Biochemical and Biophysical Methods, 53(1-3) (2002) 241-250.

[7] J. Bernatoniene, R. Masteikova, J. Davalgiene, R. Peciura, R. Gauryliene, R. Bernatoniene, D. Majiene, R. Lazauskas, G. Civinskiene, S. Velziene, J. Muselik, Z. Chalupova, Topical application of Calendula officinalis (L.): Formulation and evaluation of hydrophilic cream with antioxidant activity, Journal of Medicinal Plants Research, 5(6) (2011) 868-877.

[8] Y. M. Fonseca, C. D. Catini, F. T. Vicentini, A. Nomizo, R. F. Gerlach, M. J. V. Fonseca, Protective effect of Calendula officinalis extract against UVB-induced oxidative stress in skin: Evaluation of reduced glutathione levels and matrix metalloproteinase secretion, Journal of Ethnopharmacology, 127(3) (2010) 596-601

[9] G. S. Ćetković, S. M. Djilas, J. M. Čanadanović-Brunet, V. T. Tumbas, Antioxidant properties of marigold extracts, Food Research International, 37(7) (2004) 643-650.

[10] T. Ercetin, F. S. Senol, I. E. Orhan, G. Toker, Comparative assessment of antioxidant and cholinesterase inhibitory properties of the marigold extracts from Calendula arvensis L. and Calendula officinalis L., Industrial Crops and Products, 36(1) (2012) 203-208.

[11] M. R. García-Risco, L. Mouhid, L. Salas-Pérez, A. LópezPadilla, S. Santoyo, L. Jaime, A. R. de Molina, G. Reglero, T. Fornari, Biological activities of Asteraceae (Achillea millefolium and Calendula officinalis) and Lamiaceae (Melissa officinalis and Origanum majorana) plant extracts Plant Foods for Human Nutrition, 72(1) (2017) 96-102.

[12] T. Jurca, L. Vicas, E. Marian, S. Vicas, M. Muresan, A new natural antioxidant supplement - design and development Farmacia, 64(1) (2016) 135-142.

[13] S. Bissa, A. Bohra, Antibacterial potential of pot marigold Journal of Microbiology and Antimicrobials, 3(3) (2011) 51-54. DOI: $10.13005 / \mathrm{bbra} / 2331$

[14] E. Efstratiou, A. I. Hussain, P. S. Nigam, J. E. Moore, M. A. Ayub, J. R. Rao, Antimicrobial activity of Calendula officinalis petal extracts against fungi, as well as Gram-negative and Gram-positive clinical pathogens, Complementary Therapies in Clinical Practice, 18(3) (2012) 173-176.

[15] Z. Stojanović-Radić, Antimicrobial activity of the three commercial drug's essential oils: Chamomillae flos, Calendulae flos and Millefolii herba, Biologica Nyssana, 3(2) (2012) 69-76.

[16] R. Dawid-Pać, Medicinal plants used in treatment of inflammatory skin diseases, Postępy Dermatologii I Alergologii, 30(3) (2013) 170-177.

[17] J. T. M. Alexandre, L. H. T. Sousa, M. R. P. Lisboa, F. A. C. Furlaneto, D. R. do Val, M. Marques, H. C. Vasconcelos, I. M. de Melo, R. Leitao, G. A. C. Brito, P. Goes, Antiinflammatory and antiresorptive effects of Calendula officinalis on inflammatory bone loss in rats, Clinical Oral Investigations, 22(6) (2018) 2175-2185.

[18] K. Sak, T. H. Nguyen, V. D. Ho, T. T. Do, A. Raal, Cytotoxic effect of chamomile (Matricaria recutita) and marigold (Calendula officinalis) extracts on human melanoma SK-MEL-2 and epidermoid carcinoma KB cells, Cogent Medicine, 4 (2017) 1333218.

[19] D. Cruceriu, O. Balacescu, E. Rakosy, Calendula officinalis: Potential roles in cancer treatment and palliative care, Integrative Cancer Therapies, 17(4) (2018) 1068-1078.

[20] S. Bashir, K. H. Janbaz, Q. Jabeen, A. H. Gilani, Studies on spasmogenic and spasmolytic activities of Calendula officinalis flowers, Phytotherapy Research, 20(10) (2006) 906-910.

[21] K. C. Preethi, R. Kuttan, Hepato and reno protective action of Calendula officinalis L. flower extract, Indian Journal of Experimental Biology, 47 (2009) 163-168.

[22] European Pharmacopoeia, $6^{\text {th }}$ edition, Council of Europe, 67075 Strasbourg Cedex, France, 2007.

[23] Jugoslovenska farmakopeja 2000 (Ph.Jug. V), Savremena administracija, Beograd, 2001. (in Serbian)

[24] M. Yoshikawa, T. Murakami, A. Kishi, T. Kageura, H. Matsuda, Medicinal flowers. III. Marigold.(1): hypoglycemic, gastric emptying inhibitory, and gastroprotective principles and new oleanane-type triterpene oligoglycosides, calendasaponins A, B, C, and D, from Egyptian Calendula officinalis, Chemical and Pharmaceutical Bulletin, 49(7) (2001) 863-870.

[25] S. Moghaddasi Mohammad, H. H. Kashanisup, Pot marigold (Calendula officinalis) medicinal usage and cultivation, Scientific Research and Essays, 7(14) (2012) 1468-1472. DOI: $10.5897 /$ SRE11.630

[26] British Pharmacopoeia, H. M. S. Office, London, 1980, pp. 109-110.

[27] European Pharmacopoeia, 3rd edition, Council of Europe, Strasbourg, France, 1997

[28] G. Matysik, M. Wojciak-Kosior, R. Paduch, The influence of Calendulae officinalis flos extracts on cell cultures, 
and the chromatographic analysis of extracts, Journal of Pharmaceutical and Biomedical Analysis, 38(2) (2005) 285-292.

[29] C. Nicolaus, S. Junghanns, A. Hartmann, R. Murillo, M. Ganzera, I. Merfort, In vitro studies to evaluate the wound healing properties of Calendula officinalis extracts, Journal of Ethnopharmacology, 196 (2017) 94-103.

[30] M. Hamburger, D. Baumann, S. Adler, Supercritical carbon dioxide extraction of selected medicinal plants - effects of high pressure and added ethanol on yield of extracted substances, Phytochemical Analysis, 15(1) (2004) 46-54.

[31] L. Petrović, Ž. Lepojević, V. Sovilj, D. Adamović, V. Tešević, Composition of essential oil obtained from tubular, head and ligulate flowers of Calendula officinalis L. by steam distillation of plant material and $\mathrm{CO}_{2}$ extracts, Journal of Essential Oil Research, 22 (2010) 143-146.

[32] K. Vilkhu, R. Mawson, L. Simons, D. Bates, Applications and opportunities for ultrasound assisted extraction in the food industry - a review, Innovative Food Science \& Emerging Technologies, 9(2) (2008) 161-169.

[33] K. M. Sharif, M. M. Rahman, J. Azmir, A. Mohamed, M. H. A. Jahurul, F. Sahena, I. S. M. Zaidul, Experimental design of supercritical fluid extraction-A review, Journal of Food Engineering, 124 (2014) 105-116.

[34] J. P. Maran, S. Manikandan, K. Thirugnanasambandham, C. V. Nivetha, R. Dinesh, Box-Behnken design based statistical modeling for ultrasound-assisted extraction of corn silk polysaccharide, Carbohydrate Polymers, 92(1) (2013) 604-611.

[35] C.-C. Chang, M.-H. Yang, H.-M. Wen, J.-C. Chern, Estimation of total flavonoid content in propolis by two complementary colorimetric methods, Journal of Food and Drug Analysis, 10(3) (2002) 178-182.

[36] R. Rodríguez-Solana, J. M. Salgado, J. M. Domínguez, S. Cortés-Diéguez, Comparison of Soxhlet, accelerated solvent and supercritical fluid extraction techniques for volatile (GC-MS and GC/FID) and phenolic compounds (HPLC-ESI/MS/MS) from Lamiaceae Species, Phytochemical Analysis, 26(1) (2015) 61-71.

[37] L. Moity, M. Durand, A. Benazzouz, V. Molinier, J. M. Aubry, In silico search for alternative green solvents, In Alternative Solvents for Natural Products Extraction, F. Chemat, M. Vian (Eds.), Springer, Berlin, Heidelberg 2014, p. 1-24.

[38] R. Stoica, S. Velea, L. Ilie, M. Calugareanu, S. B. Ghimis, R.-M. Ion, The influence of ethanol concentration on the total phenolics and antioxidant activity of Scenedesmus opoliensis algal biomass extracts, Revista De Chimie (Bucha rest), 64 (2013) 304-306.

[39] K. Ravikumar, S. Ramalingam, S. Krishnan, K. Balu, Application of response surface methodology to optimize the process variables for reactive red and acid brown dye removal using a novel adsorbent, Dyes and Pigments, 70(1) (2006) 18-26.

[40] J.-H. Xie, C.-j. Dong, S.-P. Nie, F. Li, Z.-J. Wang, M.-Y. Shen, M.-Y. Xie, Extraction, chemical composition and antioxidant activity of flavonoids from Cyclocarya paliurus (Batal.) Iljinskaja leaves, Food Chemistry, 186 (2015) 97105.

[41] I. M. Savic, I. Lj. Nikolic, I. M. Savic-Gajic, T. D. Kundakovic, Modeling and optimization of bioactive compounds from chickpea seeds (Cicer arietinum L), Separation Science and Technology, 54(5) (2019) 837-846.

[42] A. Ahmad, K. M. Alkharfy, T. A. Wani, M. Raish, Application of Box-Behnken design for ultrasonic-assisted extraction of polysaccharides from Paeonia emodi. International Journal of Biological Macromolecules, 72 (2015) 990-997.

[43] K. Vilkhu, R. Mawson, L. Simons, D. Bates, Applications and opportunities for ultrasound assisted extraction in the food industry - A review, Innovative Food Science \& Emerging Technologies, 9(2) (2008) 161-169.

[44] Б. Д.Пономарев, Экстрагиробание лекартвенного сырья, Медицина, Москва, 1976.

[45] N. F. Azahar, S. S. A. Gani, N. F. M. Mokhtar, Optimization of phenolics and flavonoids extraction conditions of Curcuma Zedoaria leaves using response surface methodology, Chemistry Central Journal, 11 (2017) Article 96, 1-10.

[46] A. R. Bilia, D. Salvini, G. Mazzi, F. F. Vincieri, Characterization of calendula flower, milk-thistle fruit, and passion flower tinctures by HPLC-DAD and HPLC-MS, Chromatographia, 53(3-4) (2000) 210-215.

[47] A. R. Bilia, M. C. Bergonzi, S. Gallori, G. Mazzi, F. F. Vincieri, Stability of the constituents of calendula, milkthistle and passionflower tinctures by LC-DAD and LCMS, Journal of Pharmaceutical and Biomedical Analysis, 30(3) (2002) 613-624. 


\section{Izvod \\ POSTUPAK EKSTRAKCIJE UKUPNIH FLAVONOIDA IZ CVETA NEVENA (Calendulae officinalis L.)}

Stanko A. Zerajić, Ivana M. Savić Gajić, Ivan M. Savić, Goran S. Nikolić

(ORIGINALNI NAUČNI RAD)

Tehnološki fakultet, Univerzitet u Nišu, Leskovac, Srbija UDK 66.061:582.998:547.972.3

Neven (Calendula officinalis L.) sadrži različita bioaktivna jedinjenja, kao što su: flavonoidi, tanini, saponozidi, karotenoidi, triterpenski alkoholi, polisaharidi, aminokiseline i etarsko ulje. Ekstrakt cveta nevena blagotvorno deluje na kožu usled prisustva flavonoida koji imaju antiinflamatorno, adstrigentno, antifungalno i antiseptično dejstvo. Cilj rada bio je da se primeni ultrazvučna ekstrakcija kao savremena tehnika i da se ispita uticaj vremena ekstrakcije (5-35 min), koncentracije etanola $\left(20-80 \%\right.$, v/v) i temperatura ekstrakcije $\left(30-70{ }^{\circ} \mathrm{C}\right)$ na sadržaj ukupnih flavonoida cveta nevena pri odnosu rastvarača i biljne sirovine od $20 \mathrm{~cm}^{3} \mathrm{~g}^{-1}$. Sadržaj ukupnih flavonoida ekstrakata određen je spektrofotometrijski sa aluminijum(III) hloridom. Modelovanje ultrazvučne ekstrakcije izvršeno je primenom Box-Behnkenovog dizajna. Tako dobijeni optimalni uslovi bili su: vreme ekstrakcije od $29 \mathrm{~min}$, $39,6 \%$ (v/v) etanol i temperature ekstrakcije od 64,2 ${ }^{\circ} \mathrm{C}$. Eksperimentalna vrednost $\left(220,2 \mathrm{mg} 100 \mathrm{~g}^{-1} \mathrm{~s}\right.$.m. $)$ sadržaja ukupnih flavonoida pri optimalnim uslovima bila je u dobroj saglasnosti sa predviđenom vrednošću (221,5 mg $100 \mathrm{~g}^{-1} \mathrm{~s}$.m.). Prema rezultatima statističke analize, predložena polinomna jednačina drugog reda može se upotrebiti da opiše ekstrakciju flavonoida i da predvidi sadržaj ukupnih flavonoida. Postupak ekstrakcije može se prihvatiti sa stanovišta farmaceutske primene usled primene etanola kao predstavnika zelenih rastvarača. Vreme ekstrakcije bilo je kraće u poređenju sa drugim konvencionalnim tehnikama ekstrakcije.

Ključne reči: ultrazvučna ekstrakcija, flavonoidi, Calendulae officinalis, BoxBehnken. 